\title{
Comparative Experimental Study Between Conventional Stepped Solar Still and an Active Stepped Solar Still Incorporated with a Water Circulation System
}

\author{
Abd-Elnaby E. Kabeel, Hagar Alm El Din Mohamad, Sarah Majeed \\ Mechanical Power Engineering Department, Faculty of Engineering, Tanta University, Tanta, Egypt.
}

\begin{abstract}
In the following experimental study modifications were carried out into a stepped solar still, considerably increasing the distilled water productivity. Objective function in present study is the comparison between of an active stepped solar still provided with modifications in a new water cooling circulation depending upon an active mode by means of a PV cell incorporated for a stepped solar still, with a conventional solar still without water circulation. In the study the results of glass cover temperature, basin temperature, and fresh water productivity are collected for both stepped solar stills. Also, the solar radiation rate for a period of June 2018 to November 2018 have been carried out in order to optimize the stepped still performance and its yield as well. It was found that, these additions and modifications highly enhance the evaporation and condensation, so distillate yield was augmented. It was found that, daily distilled water productivity reached about $7.21 \mathrm{l} / \mathrm{m} 2$ day for the stepped solar still with water circulation. While corresponding value was $4.45 \mathrm{l} / \mathrm{m} 2$ day for the conventional stepped solar still at the same water depth (2) $\mathrm{cm}$ at summer times and $6.41 \mathrm{l} / \mathrm{m} 2$ day for the stepped solar still with water circulation and $3.5 \mathrm{l} / \mathrm{m} 2$ day for the conventional stepped solar still at winter times also at the same water depth. The increase in daily distillate water productivity for a stepped solar still with a PV and water circulation is about $78.24 \%$ higher than that of a conventional stepped solar still. Moreover, the average efficiency of daily freshwater productivity is $\mathbf{4 2 . 8 4} \%$ for a stepped solar still with water circulation, while it was $37 \%$ for a conventional stepped solar still, at the same water depth $2 \mathrm{~cm}$ at summer and $40.5 \%$ for a stepped solar still with water circulation and $34 \%$ for a conventional stepped solar still at winter times. The present study held under the climate conditions of Egypt at Faculty of Engineering-Tanta University, Egypt.
\end{abstract}

Index Terms-Water Desalination, stepped solar still, water productivity

\section{INTRODUCTION}

Widely known that, more than two-third of the earth's surface is covered with water. Most of the available water is either present as seawater or icebergs in the Polar Regions. More than $97 \%$ of the earth's water is salty; rest around $2.6 \%$ is fresh water. Less than $1 \%$ fresh water is within human reach. Even this small fraction is believed to be adequate to support life and vegetation on earth. Nature itself provides most of the required fresh water, through hydrological cycle. A very large-scale process of solar distillation naturally produces fresh water. The essential features of this process are thus summarized as the production of vapors above the surface of the liquids, the transport of vapors by winds, the cooling of air vapor mixture, condensation and precipitation. This natural process is copied on a small scale in basin type solar stills. [1]

Solar still is widely used in solar desalination processes. But the productivity of the solar still is very law. To increase the productivity of the single basin solar still many study works are being carried out up till now. Glass, rubber and gravel are some of things that used as thermal storage materials [2]. A solar still was tested with a special phase changing material as energy storage media at its base [3] The performance of a solar still with different size sponge cubes placed in the basin was studied experimentally [4]. The results showed that the increase of daily productivity from $18.3 \%$ to $28 \%$. Higher energy is required to heat the total water area of the solar still. Instead, the surface water alone can be heated with less energy and thus improving productivity. Floating perforated plate [5] and baffle suspended absorber plates [6] are also used.

Two common and low-cost designs for direct solar desalination include stepped solar stills and basin solar stills. the freshwater production efficiency of stepped solar stills is higher than the basin solar stills. Because in stepped solar stills, the thickness of saline water layer is less and saltwater as forced mode in the solar still flows and the evaporation rate is much higher [7]. However, electrical power is needed for pumping saline water in stepped solar still. By connecting the photovoltaic thermal (PVT) water collector, electricity power needed to pump saline water in the system can be supplied. Moreover, the PV/T collector operated as preheater of water and by raising the temperature of the saline water in the system will increase the production of fresh water. On the other hand, the electrical performance of photovoltaic cells in the PVT water collector due to cooling that with saline water would be improved. Performance analysis of stepped solar stills can provide criteria for the improvement of freshwater production. In recent years, numerous studies have been conducted on the performance analysis of stepped solar stills. The beginning of research on stepped solar stills is attributed to Khelif and Touati [8] carried out a theoretical and experimental study on the performance of a stepped solar still. They introduced three main parameters, namely optical efficiency, global losses factor, and time constant as the characterizations of solar still, and finally provided solutions to improve the performance of 
solar still by these three parameters. Headley [9-11] in the early seventies. He designed and tested a stepped solar still. His study showed that the freshwater productivity of stepped solar stills is much higher than basin solar stills. Because in stepped solar still, the thickness of saline water layer is less and consequently the rate of evaporation is higher. Kabeel et al. [12-16] used a stepped solar still and a settling tank to purify the textile effluent. Fins, sponge and pebble were used to improve the stepped solar still productivity. Abdallah et al. [17] improved the stepwise basin type solar still by installing reflecting mirrors on all interior sides. The experimental data show that the use of internal mirrors improves the still thermal performance up to $180 \%$. The performance of stepped solar still with internal and external reflectors have been investigated by [17-19]. These reflectors are used to increase solar energy input to the still. The experimental data indicates that an improvement of about $125 \%$ than the CSS was obtained using both internal and external (top and bottom) reflectors.

In the present study authors performed an experimental investigation and comparative study in order to examine effect of water circulation upon the efficiency, yield, overall productivity of a two stepped solar stills. One of the proposed solar stills is a conventional one and the other is a modified solar still with water circulation. The following experimental study was held under Egyptian conditions at the period from June 2018 to November 2018.

\section{EXPERIMENTAL SETUP}

The experimental set up was designed and applied in the Faculty of Engineering-Tanta University, Egypt (Latitude $30^{\circ} \mathrm{N}$ and longitude $31^{\circ} \mathrm{E}$ ) during the period from June 2018 to November 2018. In the present work, two stepped solar stills were designed, constructed and tested to compare the freshwater productivity by using the solar desalination technique. Two stepped solar stills are shown in Figs. (1), (2). The conventional stepped solar still is $1 \mathrm{~m}^{2}(1 \mathrm{~m} \mathrm{x} 1 \mathrm{~m})$. High-side wall depth is $450 \mathrm{~mm}$ and the low-side wall height is $160 \mathrm{~mm}$. The still is made of high quality Galvanized steel. The whole basin surfaces are coated with dark black paint from inside to increase the absorptivity. The basin still is insulated through the side and the bottom with $5 \mathrm{~cm}$ low thermal conductivity fiber glass insulation to reduce heat energy loss from the conventional stepped solar still to the ambient.

The insulation layer is supported by a wooden frame. The basin is covered with a thin clear glass sheet $4 \mathrm{~mm}$ thick inclined at nearly $30^{\circ}$ horizontally, which is the latitude of Tanta City, Egypt. The condensed water was collected through the lower end side of the cover. The feed water tank is placed $0.75 \mathrm{~m}$ above the basin still to feed the saline water to the still basin by natural circulation. A check valve used to regulate the saline water flow rate from the feed water tank to the basin still. The size of the feed water tank used is 150 liters. The absorber plate of the conventional stepped solar still is made of 5 steps (each of size $0.1 \mathrm{~m} \times 1 \mathrm{~m}$ ). The saline water tank connected to basin still by feed water flexible pipeline.
The stepped solar still with water circulation consists of the same dimension and construction of conventional stepped solar still, in addition the absorber plate is made of 5 steps (each of size $0.1 \mathrm{~m} \times 1 \mathrm{~m}$ ). The active mode of the solar still is held by a means of a PV cell in order to generate the electrical power needed for the water circulation system. A digital thermometer as well as a digital temperature sensor and Arduino) used to measure the temperature of the absorber plate (at two points), the glass cover and inlet water temperature. Also, we utilized a pyranometer and solar radiation sensors in order to capture more functions and data of present experimental study.

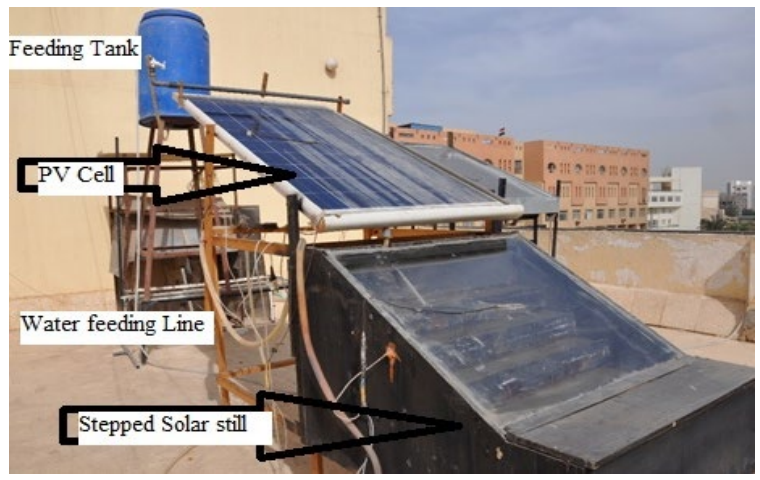

Figure 1. A photo of a stepped solar stills with PV and water circulation

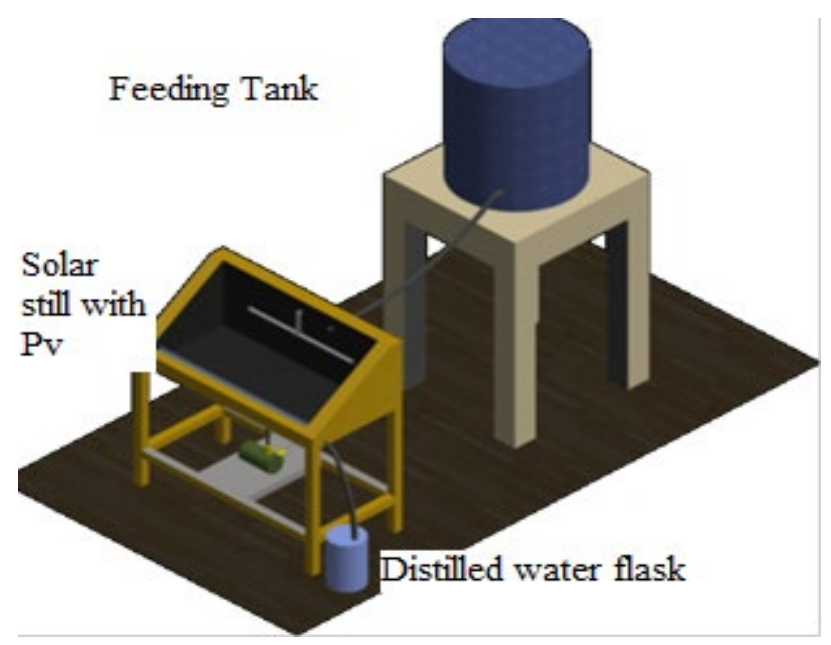

Figure 2. A schematic design of the conventional stepped solar still

\section{EXPERIMENTAL PROCEDURE}

The present experimental setup is designed, constructed, and tested in the Faculty of Engineering-Tanta University, Egypt (Latitude $30^{\circ} \mathrm{N}$ and longitude $31^{\circ} \mathrm{E}$ ). The experimental work is carried out in the period from 8:00 am to 6:00 pm. The solar radiation intensity, ambient temperature, glass cover temperature, basin water temperature were measured every 1 hour for both conventional stepped solar still and stepped solar with water circulation. For both conventional stepped solar still and stepped solar still with water circulation the freshwater productivity is measured periodically each hour. All experimental measurements aim to evaluate the freshwater productivity for both conventional 
stepped solar still and stepped solar still with water circulation under the same ambient conditions of Tanta City.

The experimental set up had been achieved at the same depth of all stills. In this study there was two groups, the first group is a conventional stepped solar still in this group the fresh water productivity are studied, the conventional stepped solar still it's used to study the effect of 5 stepped on the fresh water productivity, the second group is a stepped solar still with water circulation by means of PV cell incorporated with the still, it's used to study the effect water circulation on the fresh water productivity. All the work was done at a fixed depth through the period from 8:00 am to 6:00 pm. The depths of basin water used in the present study is $(2 \mathrm{~cm})$. The data calculated for both summer and winter season in order to evaluate the effect of climate change upon the main functions of test reg.

\section{RESULTS AND DISCUSSION}

In the present experimental work, the effect of a PV and water circulation on the performance of the stepped solar still has been studied and the effect of water cooling by circulation on the performance of the PV. A comparison between a stepped solar still with a PV and water circulation, and conventional stepped solar still was hilled to evaluate the development in the freshwater productivity at the fixed water depth of $2 \mathrm{~cm}$ and under the same ambient conditions of Tanta City, Egypt, during the period from June 2018 to November 2018 from 8:00 am to 6:00 pm.

A comparison between the hourly distilled water productivity for both stepped solar still with a PV and water circulation and conventional stepped solar still during the period from 8:00 am to 6:00 pm at summer times are shown in Fig (3-a) and at winter times are shown in fig (3-b) The productivities of the two solar stills were around 0.0 at 8:00 am, while their value recorded $1.441 / \mathrm{m}^{2}$. hour and $0.76 \mathrm{1} / \mathrm{m}^{2}$. hour at summer and their value recorded $1.12 \mathrm{l} / \mathrm{m}^{2}$. hour and $0.68 \mathrm{1} / \mathrm{m}^{2}$. hour at winter as a maximum freshwater productivity at 1:00 pm for stepped solar still with a PV and water circulation, and conventional stepped solar still, respectively.

Figure $4(\mathrm{a}, \mathrm{b})$ show a comparison between the daily distilate water productivity for the stepped solar still with a $\mathrm{PV}$ and water circulation, and the conventional stepped solar still. The results show that the daily distilate water productivity for stepped solar still with a PV and water circulation is higher than that of conventional stepped solar still along the day at summer and winter times. the daily distilate water productivity up to almost $7.21 \mathrm{l} / \mathrm{m}^{2}$ day for the stepped solar still with a PV and water circulation while its value was $4.45 \mathrm{1} / \mathrm{m}^{2}$ day for the conventional stepped solar still and $6.41 \mathrm{l} / \mathrm{m}^{2}$ day for the stepped solar still with PV and water circulation while its value was $3.51 / \mathrm{m}^{2}$ day for the conventional stepped solar still. The increase in daily distilate water productivity for stepped solar still with a PV and water circulation is $78.24 \%$ higher than that of conventional stepped solar still.

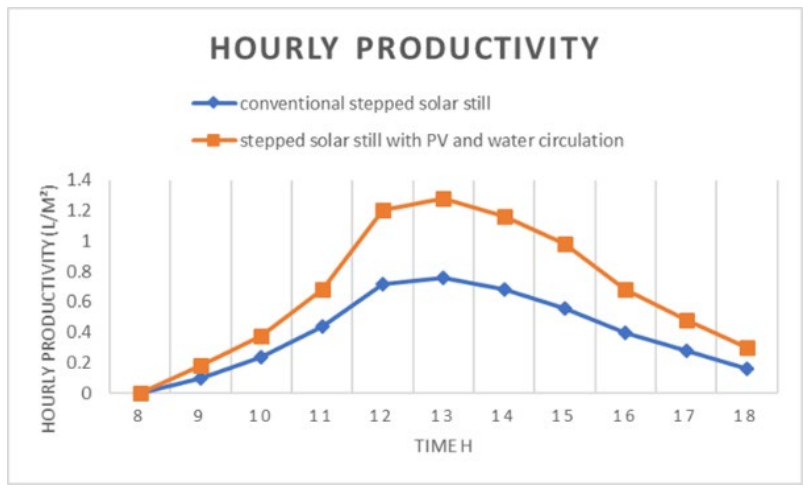

(a) Summer Season Results

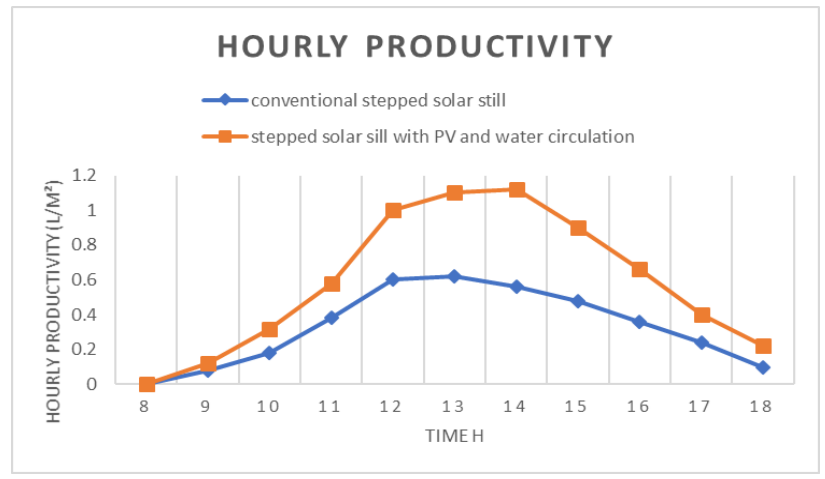

(b) Winter Season Results

Figure $3(\mathrm{a}, \mathrm{b})$. Variation of hourly productivity for solar still with PV and water circulation, and conventional solar still at summer and winter times.

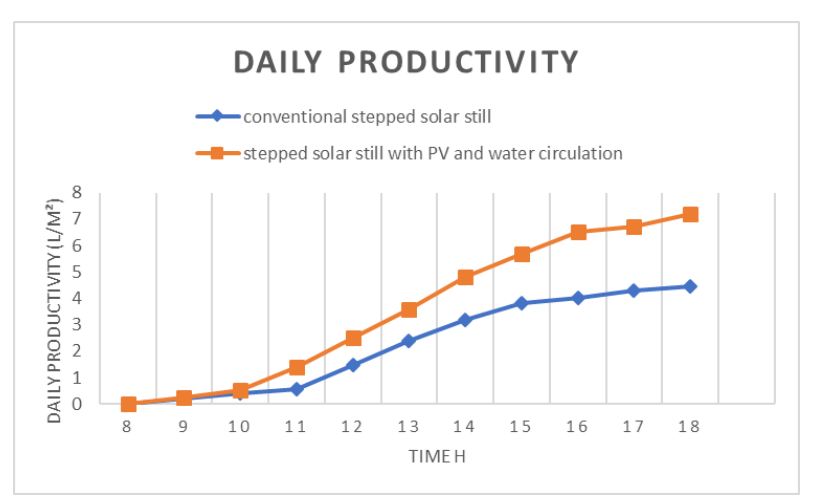

(a) Summer Season Results

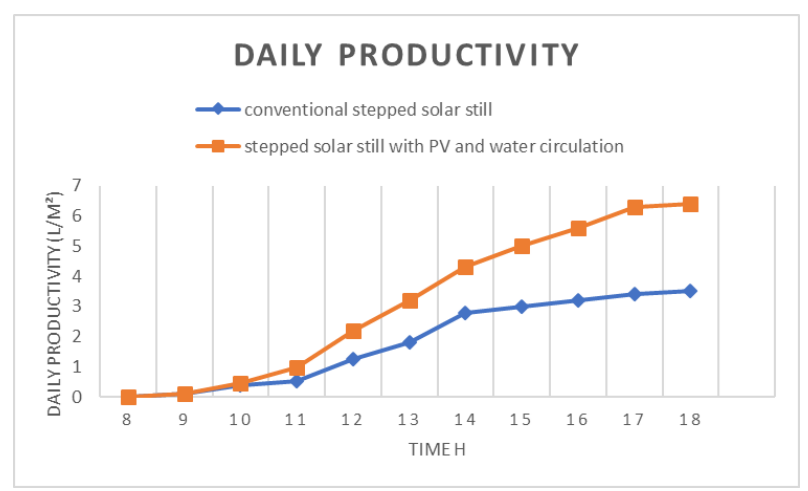

(b) Winter Season Results

Figure $4(a, b)$. The daily distillate water productivity for stepped solar still with PV and water circulation, and conventional stepped solar still at summer and winter times. 
The results presented in Figure $5(\mathrm{a}, \mathrm{b})$ show the hourly efficiency of the both stepped solar still with a PV and conventional stepped solar still in summer and winter times. As shown in this figure, the hourly efficiency for the stepped solar still with PV and water circulation is higher than that of conventional stepped solar still. The average daily efficiencies are 46.84 and $37 \%$ for stepped solar still with PV and water circulation, and conventional stepped solar still at summer times and the average daily efficiencies are $40.5 \%$ and $34 \%$ for stepped solar still with a PV and water circulation, and conventional stepped solar still at winter times

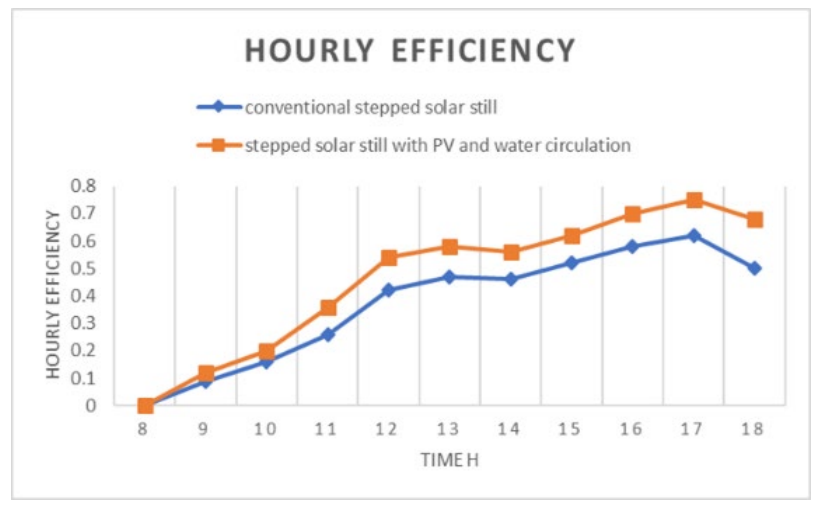

(a) Summer Season Results

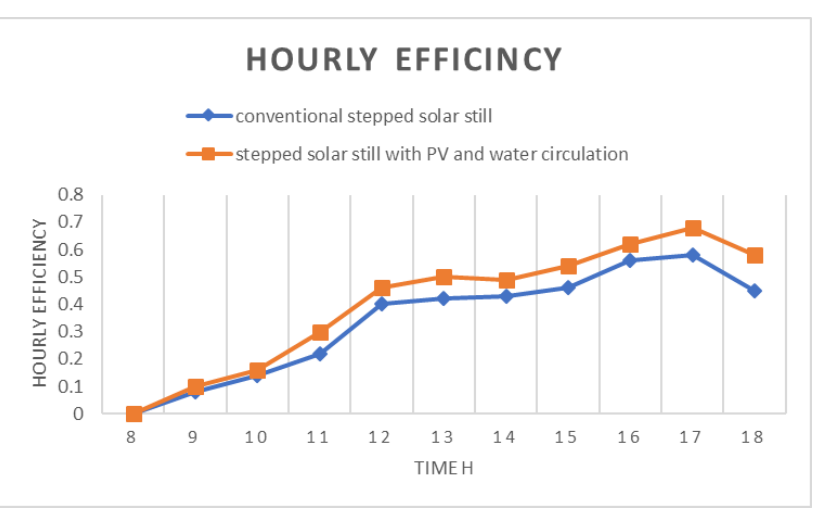

(b) Winter Season Results

Figure 5 (a,b). Hourly efficiency variation for stepped solar still with PV and water circulation, and conventional stepped solar still at summer and winter times.

Variations of solar radiation, atmospheric temperature, base temperature, basin water temperature and glass temperature of stills are shown in Fig $6(a, b)$ It is observed that the temperatures at all points increase as the time increase till a maximum value at noon and start to decrease after that. This is due to the increase of solar radiation intensity in the morning and its decrease in the afternoon. Also, from Fig. 5, it can be noticed that the glass temperature and basin water temperature of stepped solar still are higher than that of conventional still by about $0-5 \mathrm{C}^{\circ}$ and $0-10 \mathrm{C}^{\circ}$, respectively at summer times and about $0-2 \mathrm{C}^{\circ}$ and $0-7 \mathrm{C}^{\circ}$ at winter times because of the condensation rate and the amount of water in the stepped still is higher than that of conventional still.

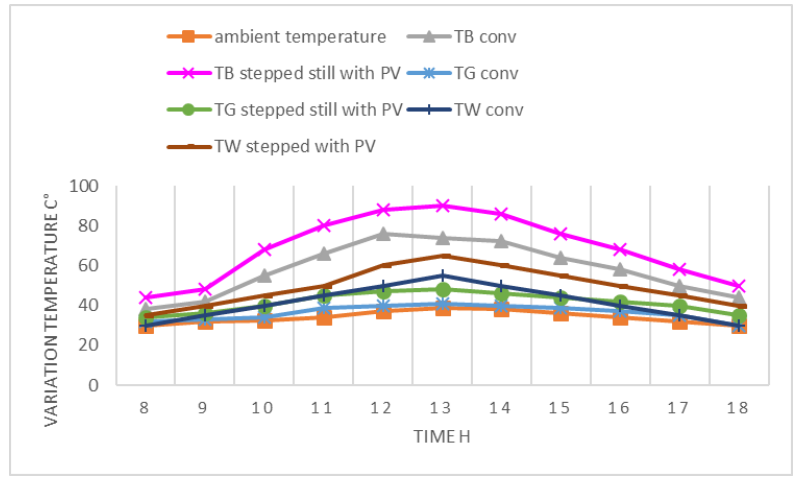

(a) Summer Season Results

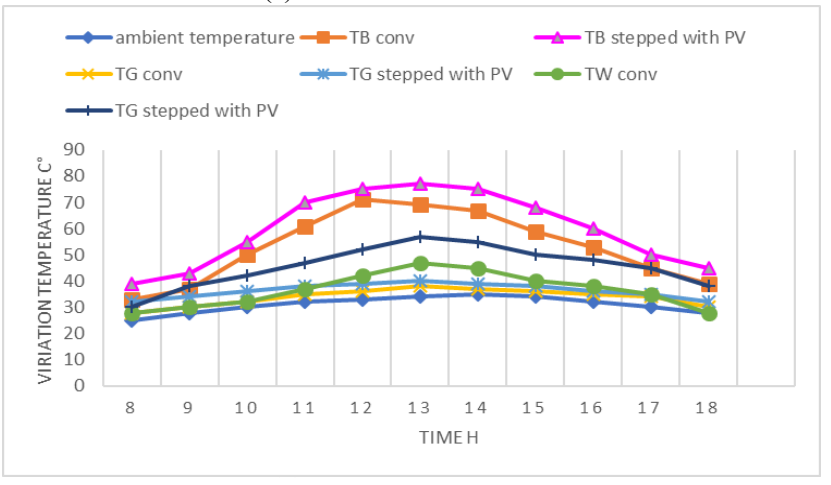

(b) Winter Season Results

Figure $6(\mathrm{a}, \mathrm{b})$. Variations of solar radiation, atmospheric temperature, base temperature, basin water temperature and glass temperature of stills at summer and winter times.

\section{CONCLUSION}

This experimental study aims to improve the performance of a PV using water cooling by spray system, as well as, improve the distillate production of developed stepped solar still using the water circulation system, the effect of a PV and water circulation on the performance of stepped solar still investigated under the ambient conditions of Tanta city (Egypt). The performance of solar still coupled with a PV and water circulation and conventional stepped solar still was examined at same basin water depth [2 $\mathrm{cm}]$.Two stepped solar stills are utilized under the same ambient conditions of Tanta City, Egypt, during the period from June 2018 to November 2018 from 8:00 am to 6:00 pm.

The following conclusions have been drawn during the study:

- The daily distilled water productivity for a stepped solar still with a PV and water circulation is higher than that of a conventional stepped solar still.

- The daily distilled water productivity reached about $7.21 \mathrm{l} / \mathrm{m} 2$ day for the stepped solar still with a PV and water circulation while its value was $4.451 / \mathrm{m} 2$ day for the conventional stepped solar still at the same water depth (2) $\mathrm{cm}$ at summer times and $6.41 \mathrm{1} / \mathrm{m} 2$ day for the stepped solar still with a PV and water circulation and $3.5 \mathrm{1} / \mathrm{m} 2$ day for the conventional stepped solar still at winter times also at the same water depth $(2) \mathrm{cm}$. The increase in daily distillate water productivity for a stepped solar still with a PV and water circulation is 
$78.24 \%$ higher than that of a conventional stepped solar still.

- The average efficiency of daily freshwater productivity is $42.84 \%$ for a stepped solar still with a PV and water circulation, while it was $37 \%$ for a conventional stepped solar still, at the same water depth $2 \mathrm{~cm}$ at summer and $40.5 \%$ for a stepped solar still with PV with water circulation and $34 \%$ for a conventional stepped solar still at winter times.

- Use water cooling for PV improved the output of electrical power generated from the $\mathrm{PV} 35 \%$ as a compared with a conventional PV.

\section{REFERENCES}

[1] Sampathkumar, K., T.V. Arjunan, P. Pitchandi and P. Senthilkumar, Active solar distillation - A detailed review, Renewable and Sustainable Energy Reviews 14 (2010) 1503-1526.

[2] Abdel-Rehima, Z.S. and A. Lasheen, "Improving the performance of solar desalination systems, Renew. Ener., 30 (2005) 1955-1971.

[3] Nafey, A.S., M. Abdelkader, A. Abdelmotalip and A.A. Mabrouk, Solar still productivity enhancement, Energy Conversion and Management, 42 (2001) 1401-1408.

[4] Naim, M.M. and M.A. Abd El Kawi, Nonconventional solar stills Part 2. Non-conventional solar stills with charcoal particles as absorber medium, Desalination, 153 (2002) 71-80.

[5] Bassam, A.K and R. Himzeh., Experimental study of a solar still with sponge cubes in basin, Energy Conversion and Management, 44 (2003) 1411-8.

[6] Nafey, A.S., M. Abdelkader, A. Abdelmotalip and A.A. Mabrouk, Enhancement of solar still productivity using floating perforated black plate, Energy Conversion and Management 43 (2002) 937946.

[7] El-Sebaii, A.A., S. Aboul-Enein and E. El-Bialy, Single basin solar still with baffle suspended absorber, Energy Conversion and Management 41 (2000) 661-675.

[8] C. Khelif, B. Touati, Semi-empirical characterization of a greenhouse-effect cascades solar distiller, Renew. Energy 19 (2000) 103-110.

[9] O.S.T.C. Headley, Cascade solar still for distilled water production, Sol. Energy 15 (1973) 245-258.

[10] Velmurugan V, Naveen Kumar KJ, Noorul Haq T, Srithar K. Performance analysis in stepped solar still for effluent desalination. Energy 2009;34:1179-86. http://dx.doi.org/10.1016/j.energy.2009.04.029

[11] El-Samadony YAF, Kabeel AE. Theoretical estimation of the optimum glass cover water film cooling parameters combinations of a stepped solar still. Energy 2014;68:744-50. http://dx.doi.org/10.1016/j.energy.2014.01.080.

[12] Kabeel AE, El-Agouz SA (2011) Review of researches and developments on solar stills. Desalination 276(1):1

[13] Omara ZM, Kabeel AE. Enhancing the stepped solar still performance using internal and external reflectors. Energy Convers Manage 2014;78:876-81. http://dx.doi. org/10.1016/j.enconman.2013.07.092.

[14] Omara ZM, Abdullah AS, Kabeel AE, Essa FA (2017) The cooling techniques of the solar stills' glass coversa review. Renew Sust Energ Rev 78:176-193

[15] Harshir SW, Elsheikh AH, Peng G, Yang N, El-Samadony MOA, Kabeel AE (2017) Thermal performance and exergy analysis of solar stills-a review. Renew Sust Energ Rev 73:521-544
[16] kabeel AE, Omar ZM, Younes MM (2015) Techniques used to improve the performance of the stepped solar still-a review. Renew Sust Energ Rev 46:178-188.

[17] Abdallah S, Badran O, Mazen Abu-Khader M. Performance evaluation of a modified design of a single slope solar still. Desalination 2008;219:222-30. http://dx.doi. org/10.1016/j.desal.2007.05.015.

[18] Murugavel, K.K., S. Sivakumar, J. Riaz Ahamed, Kn.K.S.K. Chockalingam and K. Srithar, Single basin double slope solar still with minimum basin depth and energy storing materials, Applied Energy 87 (2010) 514-523

[19] Velmurugan, V., S.S. Kumaran, N. Prabhu and K. Srithar, Productivity enhancement of stepped solar still - performance analysis. Thermal Science 12 (2008) 153-163. 